\title{
Barriers Perceived to Car-travel Reduction among China Public
}

\author{
Yuwei LIU \\ Business School Yangzhou University, Yangzhou, Jiangsu, 22127, P. R. C.
}

\begin{abstract}
Following the process of grounded theory, the author explores the barriers perceived to car-travel reduction among publics in three provincial regions of China. The results indicate that the four axial categories, i.e. attitudes toward travel modes, car-travel habits, social reference norms and the policy and business context of travel modes, obstruct the behavior of car-travel reduction. Therefore a model of barriers to car-travel reduction is constructed, and the policy implications are discussed to promote car-travel reduction.
\end{abstract}

Keywords: Sustainable travel; Car-travel Reduction; Barriers; Grounded Theory; China

\section{Introduction}

The world has witnessed the rapid growth of car-travel since the middle of the 20th century. For example, car-travel continues to be the most popular mode in developed countries despite some attempts to restrain its increase (Ben-Elia \& Shiftan, 2013), while in developing countries, especially in China and India, the increase in car-travel has been rapidly emulating the developed world (Dargay \& Gately, 2010). Consequently, problems related to urban transportation have been increasingly serious. Therefore it is urgent for the world to reduce the existing amount of car-travel or at least to prevent it from a further growth, especially in China.

As to China, it is necessary to control car-travel and advocate the sustainable travel in the whole society, which means reducing the consumption of fossil energy in transportation, and adopting an eco-friendly travel mode such as walking, cycling or public transportation (Prillwitz \& Barr, 2011). However, there are a number of barriers to the implementation of car-travel reduction among the public. In order to promote sustainable travel, it is necessary to identify the barriers to implementation of car-travel reduction among the public, as follows of McKenzie-Mohr (2011).

This paper presents data from a qualitative study involving non-professional car drivers in China. The research questions addressed in this study are: What are the main internal and external barriers obstructing driver's intention of reducing car-travel? What are the attitudes towards car-travel reduction? How car-travel reduction is perceived and evaluated? What model can be used to explain barriers to it? To explore these questions, a series of in-depth interviews were conducted in three provincial regions of East China. Finally, a model of barriers to car-travel reduction is constructed, and the policy implications discussed to promote car-travel reduction.

\section{Methods and data source}

Given that the level of integrated transportation management in China is not high, there is little research on car-travel reduction among the public, let alone the existing variable category, scale and research hypothesis about it. Moreover, many people have different understandings of the car-travel reduction, even misunderstand and object to it. Hence interviews on the representatives are required to conduct through semi-structural questionnaire (or open-ended questionnaire) so that primary data could be collected, and resorting to the qualitative research method to explore the framework of the barriers to the car-travel reduction enables us to do the research effectively. Grounded theory is a kind of qualitative research method which was developed by Glaser and Strauss (1967), and it is particularly suitable for micro, action-oriented social interaction research. Following grounded theory, researchers summarize the procedures for collecting and analyzing data directly instead of putting forward theoretical hypothesis before conducting the survey, so it is quite different from quantitative empirical research. Based on grounded theory, data analysis involved generating concepts through the process of coding which, '... represents the operations by which data are broken down, conceptualized, and put back together in new ways. It is the central process by which theories are built from data (Strauss \& Corbin, 1990, p. 57). During the process of simultaneous collection of data and the analysis, researchers refine the concepts which reflect the social phenomenon, and then develop the category and the connection between categories, and finally they will build up their theory. There are three types of coding: open coding, axial coding, and selective coding in the process of data analysis.

In this paper, in-depth interviews of non-professional drivers as were performed individually, and each interview lasted from 30 to 60 minutes. Such interviews could give the interviewees enough time to consider the questions and express their opinions, and the interviewers could observe the changes of interviewees' appearance and action in detail, so that interviewers 
could get to know the interviewees' attitudes and feelings towards the car-travel reduction and the motives underpinning it as well. All the interviews were recorded with the consent of the interviewees and the sound records were sorted out after finishing every interview. Finally the coding analysis and model construction were based on chosen records of 26 interviewees.

\section{Data analysis and model construction}

\subsection{Open coding}

Open coding refers to labeling and categorizing of phenomena as indicated by the data. The product of labeling and categorizing is concepts - the basic building blocks in grounded theory construction. According to the method of data analysis in grounded theory, the researcher conducted the open coding on the documents of 26 interviewees and labeled the completed open coding into several categories. Since there are various overlapping concepts, and categories are the reclassification and combination of the concepts, subsequently these concepts are re-combined into categories. Table 1 indicates 18 categories and their meanings.

\section{Table 1 Open Coding}

\begin{tabular}{|c|c|c|}
\hline Concept & Brief description & Original statement \\
\hline Egocentrism & $\begin{array}{l}\text { The idea of self-interest is natural and } \\
\text { people who stick to self-interest regard } \\
\text { personal interest as the baseline of } \\
\text { attitude and behavioral norm. }\end{array}$ & $\begin{array}{l}\text { "My daily commute, career and family are much important, and they are closely connected } \\
\text { to me." "The problems of transport and environment are also important, but I don't care } \\
\text { too much since I could hardly do anything to make a change." }\end{array}$ \\
\hline $\begin{array}{l}\text { Limited perception } \\
\text { on environmental } \\
\text { problems }\end{array}$ & $\begin{array}{l}\text { People confuse or lack information, } \\
\text { knowledge, experience, understanding } \\
\text { and consciousness of causal } \\
\text { relationship and solutions of } \\
\text { environmental problems. }\end{array}$ & $\begin{array}{l}\text { "The traffic congestion is mainly caused by the imperfect road facilities and deficient } \\
\text { public transportation system." "As far as I am concerned, the large amount of private cars } \\
\text { is just one cause of the air pollution, the emission of industries, the quality of fuel, the } \\
\text { treatment of sewage also result in air pollution." }\end{array}$ \\
\hline $\begin{array}{l}\text { External attribution } \\
\text { of environmental } \\
\text { responsibility }\end{array}$ & $\begin{array}{l}\text { When it comes to the causes and } \\
\text { solutions of environmental problem, the } \\
\text { public attribute the responsibility and } \\
\text { mistakes to the external factors, such as } \\
\text { government and industrial business. }\end{array}$ & $\begin{array}{l}\text { "The greater the power, the greater the responsibility. In China, the political leaders should } \\
\text { bear the responsibility." "The regime of our country decides who has the right to organize } \\
\text { and implement the policy; others just wait for the policy to be introduced." }\end{array}$ \\
\hline $\begin{array}{l}\text { Positive attitude } \\
\text { towards car-travel }\end{array}$ & $\begin{array}{l}\text { Car-travel can optimize positive } \\
\text { emotion, individual space, save travel } \\
\text { time, energy and cost, also control } \\
\text { negative emotion. }\end{array}$ & $\begin{array}{l}\text { "We will not change our travel mode (car-travel), because driving a car is not only } \\
\text { relaxing, comfortable and quick, what's more, it is a kind of life experience and positive } \\
\text { emotion." }\end{array}$ \\
\hline $\begin{array}{l}\text { Lack of information } \\
\text { of Sustainable travel } \\
\text { and negative attitude }\end{array}$ & $\begin{array}{l}\text { Most people think that sustainable } \\
\text { travel mode is inconvenient, wastes too } \\
\text { much time and also lacks private space. }\end{array}$ & $\begin{array}{l}\text { "I will still choose a car. It is hard to change my mind. Since our living standard has } \\
\text { improved, in order to enjoy life better, we bought a car." "There's no wonder why we are } \\
\text { unwilling to take a bus and waste our time to wait for a bus." }\end{array}$ \\
\hline $\begin{array}{l}\text { Lack of self-efficacy } \\
\text { on behavior change }\end{array}$ & $\begin{array}{l}\text { When confronted with the serious } \\
\text { environmental problem, quite a lot of } \\
\text { people think that they could do nothing } \\
\text { individually. }\end{array}$ & $\begin{array}{l}\text { "Our individual could do nothing. The cities are getting crowded, people's behavior } \\
\text { (travel) mode is changing, and the total need is increasing." "There's nothing we can do } \\
\text { except so called social morality (responsibility) brought by individual." }\end{array}$ \\
\hline $\begin{array}{c}\text { Lifestyle of } \\
\text { car-travel }\end{array}$ & $\begin{array}{l}\text { The change of car-travel mode means } \\
\text { lower living standard. }\end{array}$ & $\begin{array}{l}\text { "No matter go to work or go to somewhere, to some degree, car-travel has become a } \\
\text { necessity of our social life." }\end{array}$ \\
\hline $\begin{array}{l}\text { Investment of buying } \\
\text { and using a car }\end{array}$ & $\begin{array}{l}\text { Once a person invests money on } \\
\text { something, it is more difficult to } \\
\text { abandon it than never invest money on } \\
\text { it. }\end{array}$ & $\begin{array}{l}\text { "The intention of buying a car is to liberate our legs. The insurance is accepted at the } \\
\text { beginning of the purchase." "I buy a car in order to drive it. The car is still experiencing } \\
\text { the process of depreciation even though you bought it and never used it." }\end{array}$ \\
\hline Habit of car-travel & $\begin{array}{l}\text { Our car-travel habit formed and inertia } \\
\text { developed, it is difficult to make a } \\
\text { change. }\end{array}$ & $\begin{array}{l}\text { "I have been driving for } 10 \text { years, and the total distance I drive can reach more than } 20,000 \\
\text { kilometers." "The habitual car-travel impedes the change of our travel behavior, and its } \\
\text { convenience of car-travel can make people difficult to choose alternative modes." }\end{array}$ \\
\hline $\begin{array}{l}\text { Weather condition, } \\
\text { distance, time and } \\
\text { physical effort of } \\
\text { travel }\end{array}$ & $\begin{array}{l}\text { The weather condition, distance, time } \\
\text { and physical effort of travel influence } \\
\text { the choice of travel modes. }\end{array}$ & $\begin{array}{l}\text { "It bothers me a lot when summer comes; the sweat runs down like raindrops when I am } \\
\text { waiting for the bus. Sometimes, I have to pinch the time since the bus seldom arrives at the } \\
\text { station on time." "When I have an appointment with others, I prefer to drive a car, because } \\
\text { the time is in my control." }\end{array}$ \\
\hline $\begin{array}{l}\text { Social tendency of } \\
\text { encouraging } \\
\text { car-travel }\end{array}$ & $\begin{array}{l}\text { Social tendency and reference can lead } \\
\text { the car-travel move towards the } \\
\text { requirement of social norms. }\end{array}$ & $\begin{array}{l}\text { "It is of great convenience to own and use a car." "This is also a symbol of the rapid } \\
\text { development of social economy and the improvement of people's living standard." }\end{array}$ \\
\hline Group pressure & The group pressure and social & "My colleagues will surely feel strange if I ride a bike or take a bus to go to work instead \\
\hline
\end{tabular}




\begin{tabular}{|c|c|c|}
\hline caused by car-travel & $\begin{array}{l}\text { assessment can make the drivers' } \\
\text { car-travel move towards the } \\
\text { requirement of group pressure. }\end{array}$ & of driving my car, and in their minds my brain is sick." \\
\hline $\begin{array}{c}\text { Concern about 'Free } \\
\text { Ride' effect }\end{array}$ & $\begin{array}{l}\text { If others fail to reduce car-travel, the } \\
\text { concern about being the victims of } \\
\text { "Free Ride" generated. }\end{array}$ & $\begin{array}{l}\text { "The change of travel mode is decided by the objective condition, but if the people around } \\
\text { me are unwilling to make a change, why I become a sitting duck to give up the car-travel } \\
\text { mode?" }\end{array}$ \\
\hline $\begin{array}{l}\text { Nonfeasance of some } \\
\text { officials and public } \\
\text { figures }\end{array}$ & $\begin{array}{l}\text { The public are in line with the some } \\
\text { officials' and public figures' usage of } \\
\text { car. }\end{array}$ & $\begin{array}{l}\text { "The public figures should play an exemplary role, that's why the government advocates } \\
\text { diligence and thriftiness and opposes extravagance and waste." "If I gave up the car-travel } \\
\text { mode, while the officials don't, it may cause the asymmetry of efficiency." }\end{array}$ \\
\hline $\begin{array}{l}\text { Industrial policy of } \\
\text { encouraging car } \\
\text { consumption }\end{array}$ & $\begin{array}{l}\text { The governments cultivated a kind of } \\
\text { car market which mainly depends on } \\
\text { individual consumption, and improve } \\
\text { the environment of car-travel. }\end{array}$ & $\begin{array}{l}\text { "Recently, the government offers us subsidy to buy cars; it means that the government } \\
\text { encourages the behavior of consumption." "To offer money while to use cars is forbidden, } \\
\text { it is ridiculous. Since I own a car, why not use it? I have the right to use the car." }\end{array}$ \\
\hline $\begin{array}{l}\text { Poor implementation } \\
\text { of priority to public } \\
\text { transportation }\end{array}$ & $\begin{array}{l}\text { Investment on public transport is } \\
\text { insufficient, the policy of priority to PT } \\
\text { not in place, and the environment of PT } \\
\text { management worsening. }\end{array}$ & $\begin{array}{l}\text { "Taking a bus costs quite a lot of time. Waiting for the bus in the station in front of } \\
\text { residential areas, the longest time I spend waiting for the bus is } 20 \text { minutes, sometimes the } \\
\text { bus is so crowded that it fails to stop in some bus stations." }\end{array}$ \\
\hline $\begin{array}{c}\text { Insufficiency of low } \\
\text { carbon } \\
\text { transportation } \\
\text { facilities } \\
\end{array}$ & $\begin{array}{l}\text { The priority of car-travel encroach the } \\
\text { road space for cycling and walking and } \\
\text { the low-carbon transport facilities } \\
\text { become inconvenient and scarce. }\end{array}$ & $\begin{array}{l}\text { "Have you ever felt that the road become wider, while riding a bike has become more } \\
\text { difficult?" "Dangerous! Our country encourages us to adopt sustainable travel mode, but } \\
\text { the bike lane is too shoddy." }\end{array}$ \\
\hline $\begin{array}{c}\text { Advertisements of } \\
\text { car-travel }\end{array}$ & $\begin{array}{l}\text { The advertisements which advocate } \\
\text { speed, control, comfort, enjoyment and } \\
\text { social status of cars publicize the public } \\
\text { the advantages of car-travel. }\end{array}$ & $\begin{array}{l}\text { "The car advertisements are everywhere, we hope that more and more people can buy our } \\
\text { car." "If all the people get rid of the dependence on car, the automobile industry will } \\
\text { decline." }\end{array}$ \\
\hline
\end{tabular}

\subsection{Axial coding}

Axial coding refers to the process of developing main categories and their sub-categories which have been gotten in the open coding. Through the axial coding, this research induces four axial categories, and the meanings and the categories of open coding are as shown in Table 2.

\section{Table 2 Axial Coding and Description}

\begin{tabular}{|c|c|c|}
\hline Axi & Corresponding concept & The connotation of relationship \\
\hline $\begin{array}{l}\text { Personal value, } \\
\text { environmental } \\
\text { perception and } \\
\text { attitudes towards } \\
\text { travel modes }\end{array}$ & $\begin{array}{l}\text { Egocentrism, limited perception on } \\
\text { environmental problem, external } \\
\text { attribution of environmental } \\
\text { responsibility, lack of information } \\
\text { of sustainable travel and negative } \\
\text { attitudes, lack of efficiency of } \\
\text { behavior change. }\end{array}$ & $\begin{array}{l}\text { Many factors influence the formation of barriers to car-travel reduction, such as egocentrism, } \\
\text { the limited perception of environmental problem and the external attribution of environmental } \\
\text { responsibility. People's positive attitudes towards car-travel, lack of information of sustainable } \\
\text { travel and negative attitudes towards sustainable travel modes become the direct barrier to } \\
\text { car-travel reduction. Moreover people's ignorance of the importance of behavior efficiency on } \\
\text { car-travel reduction also is related to the formation of barrier to car-travel reduction. }\end{array}$ \\
\hline $\begin{array}{c}\text { Individual } \\
\text { investment on car, } \\
\text { ability and travel } \\
\text { habit }\end{array}$ & $\begin{array}{l}\text { Lifestyle of car-travel, investment } \\
\text { on car purchase and usage, habit of } \\
\text { car-travel, influence brought by } \\
\text { weather, distance, time, and } \\
\text { traveler's physical efforts when go } \\
\text { on a trip. }\end{array}$ & $\begin{array}{l}\text { People's materialistic lifestyle and consumption concept are the psychological cost of } \\
\text { implementation of car-travel reduction. The investment on car purchase and usage results in } \\
\text { people's persistence on car-travel behavior, meanwhile the habit of car consumption directly } \\
\text { resists car-travel reduction, and the weather, distance, time and individual physical efforts can } \\
\text { influence people's ability of implementing reduction of car-travel. }\end{array}$ \\
\hline $\begin{array}{c}\text { Social and } \\
\text { contextual factors of } \\
\text { car-travel }\end{array}$ & $\begin{array}{l}\text { Social tendency of encouraging car- } \\
\text { travel, group pressure of car-travel, } \\
\text { concern about the effect of "Free } \\
\text { Ride", nonfeasance of some } \\
\text { officials and public figures. }\end{array}$ & $\begin{array}{l}\text { The social tendency of encouraging car-travel, group pressure of car-travel and social } \\
\text { intercourse will make drivers' car-travel behavior tend to the requirement of social norm. The } \\
\text { concern about becoming the victims of "Free Ride" is one reason of individual inaction of the } \\
\text { car-travel reduction, besides, the nonfeasance of some officials and public figures is often } \\
\text { regarded as the excuse of inaction. }\end{array}$ \\
\hline $\begin{array}{l}\text { Policies of transport } \\
\text { modes and } \\
\text { commercial factors }\end{array}$ & $\begin{array}{l}\text { Industrial policies of encouraging } \\
\text { car consumption, poor } \\
\text { implementation of priority to public } \\
\text { transport, insufficient of low-carbon } \\
\text { transport facilities, advertisements } \\
\text { on car-travel. }\end{array}$ & $\begin{array}{l}\text { The industrial policies of encouraging car consumption influence the regime context of the } \\
\text { implementation of car-travel reduction policy. Furthermore the poor implementation of priority } \\
\text { public transport and insufficient of low carbon transport facilities influence the technical } \\
\text { context of the implementation of car-travel travel reduction. The advertisements which } \\
\text { emphasize the advantages of car-travel become the commercial context which impedes the } \\
\text { implementation of car-travel reduction. }\end{array}$ \\
\hline
\end{tabular}




\subsection{Selective coding}

Generally, selective coding involves the integration of the categories. Selective coding thus refines the core categories from the axial categories, analyses the links between core categories, axial categories and the other categories that have been developed to form the initial theoretical framework. Accordingly, we centered on the core category the barriers to car-travel reduction, then summarized four axial categories around it, which significantly influence the implementation of car-travel reduction policy:
(1) personal value, environmental perception and the attitudes towards different travel modes;

(2) individual investment on car, individual ability and the habit of travel behavior;

(3) social and contextual factors of car-travel;

(4) political and commercial factors of car-travel.

Therefore, this research put forward the theoretical frame of the barriers to the car-travel reduction, which is called "the model of barriers to the car-travel reduction" (shown in Fig 1). The specific relationship of such model is as follows:

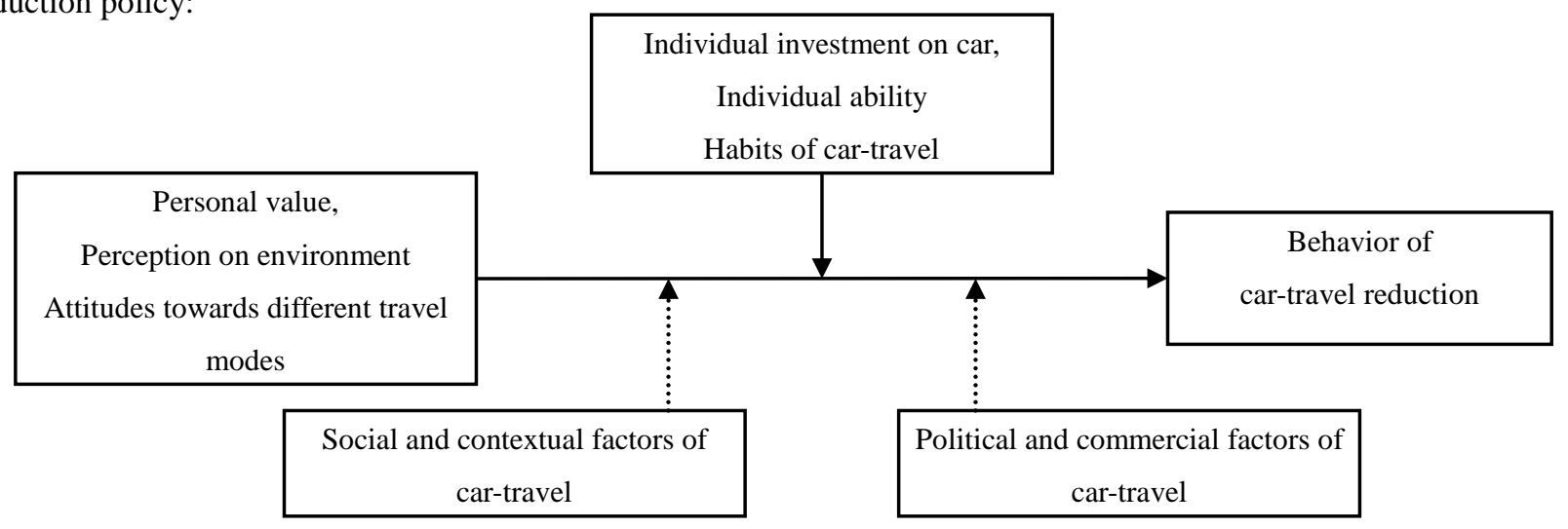

Fig 1 The model of attitudinal, behavioral and contextual factors of barriers to car-travel reduction

The internal determinant of barriers to car-travel reduction is the attitudes towards travel modes which are determined by many factors, such as egocentric value, limited perceptions on environmental problems, external attribution of environmental responsibilities, positive attitudes towards car-travel, lack of information of sustainable travel and negative attitudes and the self-efficiency of travel behavior change. These attitudes influence people's psychological preference of car-travel reduction, which forms the direct barriers to it.

The internal contextual factor of fulfilling car-travel reduction is the habit of car-travel which is determined by the factors such as the car-travel life style, the investments on the car purchase and use, the habit of car-travel, the weather, distance, limited time and energy when go on a trip. These factors prompt the occurrence of barriers to the car-travel reduction. The external contextual factors of fulfilling car-travel reduction are social reference norms, and political and commercial context of travel mode, the former depends on the social tendency of encouraging car-travel, group pressure of car-travel, concern about being the victim of "free ride" and nonfeasance of some officials and public figures, and the latter is determined by political and commercial factors, such as industrial policies which encourage car consumption, poor implementation of priority to public transport, insufficiency of the low carbon transport facilities and the advertisements on car-travel. The external contextual factors reinforce the barriers to car-travel reduction among the public. All these three variables, i.e. habit of car-travel, social reference norm and political and commercial context of travel mode, contribute to the effect through the relationship between attitudes towards travel modes and behavior of car-travel reduction, thus they are moderators in this model.

\section{Conclusions}

This research conducted an exploratory qualitative study on the barriers to the car-travel reduction in three provincial districts of China, and constructed a preliminary model of them, based on the grounded theory. Such a theoretical model not only categorized the relationship of personal value, environmental perception, attribution of environmental responsibility, attitudes towards travel modes and the behavior of car-travel reduction, but also stated categorically that car-travel habit, social reference norm, political and commercial context of travel mode moderate the intensity of the relationship between attitudes towards travel modes and the barriers to the car-travel reduction. These findings are in line with $\mathrm{ABC}$ theory by Stern and his colleagues $(2000,1999)$ who argued the causal variables of particular environmentally significant behaviors might be categorized into four major types: attitudinal factors, contextual forces, personal capabilities and habit or routine. Therefore this research was aimed at enriching the theoretical framework of sustainable travel behavior. The reliability and validity of such a model needs to be tested since the research 
method of this research is based on grounded theory, thus in future research we should conceptualize the variables in the model, design a measurement scale, and examine the relationships of the variables in the model through questionnaire or social experiment of car-travel behavior.

This research also offered some suggestions on the traffic management policy to overcome barriers to car-travel reduction. First of all, some inventions are needed to increase people's positive attitude towards sustainable travel modes. To be specific, environmental education in the entire society should be enhanced through different ways, in order to make the public perceive climate change and environmental crises properly, and arouse people's awareness of responsibility of environmental problems. Then the public should be guided to develop a kind of individual awareness of environmental responsibility and action---"start from me, start from now", which can be used as a precursor to promote the sustainable travel mode in the society. Additionally the public should be provided with information and knowledge of sustainable travel which highlights the positive effects generated by change of travel modes and lifestyle. Secondly, various measures of transport development and management should be implemented. For example, congestion charge and fuel tariff should be introduced in order to restrain individual car-travel through the increase of car-travel cost, additionally, the quality of the public transport service should be improved, and individualized marketing should be carried out to lower people's psychological costs of car-travel reduction, and to guide and stimulate the public to reduce car-travel voluntarily. Thirdly, extravagance and waste in consumption should be rectified for the sake of being responsible for our next generations, natural environment and the other people, especially demonstration effect of car-travel reduction from government agencies, officials and public figures can be significant in the respect of change of consumption atmosphere. How to limit the excessive publicity of automobile advertisements properly is one of serious matters which should be considered carefully.

\section{Acknowledgments}

This work is supported by the Natural Science Foundation of China (No.71273222).

\section{References}

[1] Ben-Elia, E., and Y. Shiftan, 2013. "Understanding behavioral change: An international perspective on sustainable travel behaviors and their motivations." J. Transport Policy, 26, 1-3.

[2] Dargay, J. M., and D. Gately, 2010. "World oil demand's shift toward faster growing and less price-responsive products and regions." J. Energy Policy, 38(10), 6261-6277.
[3] Glaser, B. G., and A. L. Strauss, 1967. "The discovery of grounded theory: Strategies for qualitative research." New York: Aldin.

[4] McKenzie-Mohr, D. 2011. "Fostering sustainable behavior: An introduction to community-based social marketing”. New society publishers.

[5] Prillwitz, J., and S. Barr, 2011. "Moving towards sustainability? Mobility styles, attitudes and individual travel behavior." J. Journal of transport geography, 19(6), 1590-1600.

[6] Stern, P. C., 2000. "New environmental theories: toward a coherent theory of environmentally significant behavior." J. Journal of social issues, 56(3), 407-424.

[7] Stern, P. C., T. Dietz, T. Abel, G. A. Guagnano, and L. Kalof, 1999. "A value-belief-norm theory of support for social movements: The case of environmentalism." J. Human ecology review, 6(2), 81-98.

[8] Strauss, A., and J. M. Corbin, 1990. "Basics of qualitative research: Grounded theory procedures and techniques”. London: Sage Publications, Inc. 